\title{
A clinical and genetic study of Hunter's syndrome. 1 Heterogeneity
}

\author{
I D YOUNG, P S HARPER, I M ARCHER, AND R G NEWCOMBE
}

From the Departments of Medical Genetics and Medical Statistics, University Hospital of Wales and the Welsh National School of Medicine, Cardiff.

SUMMARY Analysis of the natural history in 88 patients with definite or probable Hunter's syndrome indicates that the disease shows both clinical and genetic heterogeneity. Intrafamilial variation was noted in only one of 17 families. Linkage analysis suggests that the Hunter and $\mathrm{Xg}$ loci are unlikely to be closely linked.

The genetic mucopolysaccharidoses are known to be an extremely heterogeneous group of conditions. A recent classification indicates that at least 16 different forms may exist. ${ }^{1}$ However, it is still unclear whether Hunter's syndrome (mucopolysaccharidosis II), which classically shows $X$ linkage, is itself heterogeneous. One school of thought, the 'splitters', supports the concept of true clinical and genetic heterogeneity, ${ }^{2} 3$ while the opposing school, the 'lumpers', argues that 'mild' and 'severe' forms of the disease may occur within a family, ${ }^{45}$ an observation consistent with the existence of a single mutant gene, the clinical effects of which may be modified by other genetic or environmental factors or both.

The present study was undertaken to investigate whether patients with Hunter's syndrome can be readily subdivided into two clear groups, and also to assess to what extent intrafamilial variation occurs. The results of a study of linkage between the Hunter and $\mathrm{Xg}$ loci are also reported.

\section{Patients ascertained}

An introductory letter was sent to approximately 600 paediatricians throughout the United Kingdom. As a result 88 patients, all male, were ascertained in

Received for publication 17 March 1982. whom the diagnosis of Hunter's syndrome could be considered either definite (66) or probable (22). To be classified as definite each case had to belong to an undoubted $\mathrm{X}$ linked pedigree with cases in more than one sibship, or to have had biochemical confirmation of the diagnosis based on assay of iduronate sulphatase activity, or both. The biochemical methods have been reported elsewhere. ${ }^{6}$ Those cases with a typical Hunter phenotype and increased mucopolysacchariduria with excess excretion of both dermatan and heparan sulphates, but in whom no definitive assay could be performed, were classified as probable.

The 88 cases are subdivided in table 1 depending on whether they were familial or isolated, definite or probable. Attempts were made to visit as many living cases as possible, but geographical inaccessibility and unsuitable domestic circumstances sometimes precluded personal contact.

\section{Results}

\section{CLINICAL HETEROGENEITY}

In 1972 Lichtenstein $e t a l^{2}$ and Spranger ${ }^{3}$ independently concluded that the primary distinguishing feature between the apparent mild and severe forms of the disease relates to intellectual performance. In the present study formal intellectual assessments

TABLE 1 Patients ascertained in the study.

\begin{tabular}{|c|c|c|c|c|c|c|c|c|c|c|}
\hline & \multicolumn{4}{|l|}{ Familial } & \multicolumn{3}{|c|}{ Isolated } & \multicolumn{3}{|l|}{ Total } \\
\hline & $\begin{array}{l}\text { No of } \\
\text { families }\end{array}$ & $\begin{array}{l}\text { No of } \\
\text { cases }\end{array}$ & $\begin{array}{l}\text { Still } \\
\text { alive }\end{array}$ & $\begin{array}{l}\text { Personally } \\
\text { examined }\end{array}$ & $\begin{array}{l}\text { No of } \\
\text { cases }\end{array}$ & $\begin{array}{l}\text { Still } \\
\text { alive }\end{array}$ & $\begin{array}{l}\text { Personally } \\
\text { examined }\end{array}$ & $\begin{array}{l}\text { No of } \\
\text { cases }\end{array}$ & $\begin{array}{l}\text { Still } \\
\text { alive }\end{array}$ & $\begin{array}{l}\text { Personally } \\
\text { examined }\end{array}$ \\
\hline $\begin{array}{l}\text { Definite } \\
\text { Probable } \\
\text { Total }\end{array}$ & $\begin{array}{r}14 \\
3 \\
17\end{array}$ & $\begin{array}{r}43 \\
8 \\
51\end{array}$ & $\begin{array}{r}17 \\
1 \\
18\end{array}$ & $\begin{array}{r}15 \\
1 \\
16\end{array}$ & $\begin{array}{l}23 \\
14 \\
37 \\
\end{array}$ & $\begin{array}{r}20 \\
9 \\
29\end{array}$ & $\begin{array}{r}14 \\
1 \\
15\end{array}$ & $\begin{array}{l}66 \\
22 \\
88\end{array}$ & $\begin{array}{l}37 \\
10 \\
47\end{array}$ & $\begin{array}{r}29 \\
2 \\
31\end{array}$ \\
\hline
\end{tabular}




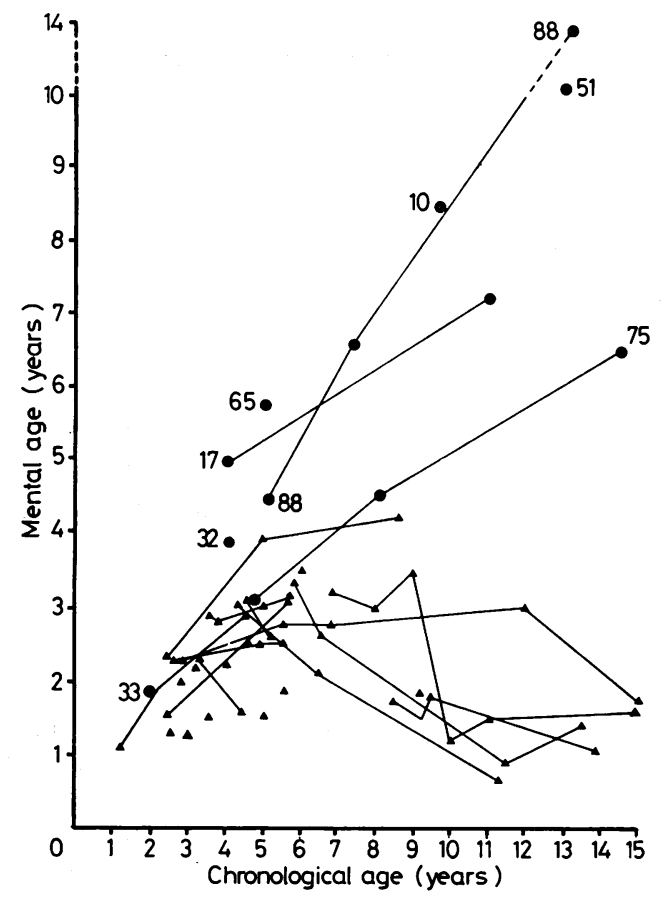

FIG 1 Mental age versus chronological age based on formal assessments of IQ. Results in those patients able to attend normal school are indicated by means of a circle, and in those unable to attend by a triangle. Numbers refer to the patient in the study.

had been performed on 33 of the 88 patients. These results are plotted in fig 1 which compares chronological with mental age. It is apparent that the patients do tend to fall into two groups.

Cases 17 and 75 are worthy of separate discussion. Case 17 came from a large enigmatic X linked kindred, subsequently referred to as family $\mathrm{G}$ and described more fully later in this paper. Case 75 died of cardiac failure at the age of 25 years. Although he scored consistently badly on formal intelligence tests, he was able to attend school and to conduct an intelligent interview with a consultant psychiatrist when aged 18 years. He never showed evidence of the severe neurodegeneration and regression which characterised the disease course of the severely affected patients.

There were 34 patients in the study who had had significantly impaired intellectual ability at the age of 4 to 6 years, as judged by either formal assessment or inability to attend normal school, and in whom the final disease outcome was known. Case 75 was the only boy in this group not to show progressive deterioration in intellectual and neurological function.

Of the 88 study patients, 76 could be readily subdivided into two groups. The first group consisted of 52 cases comprising the 33 boys who had shown progressive retardation plus 19 boys who had already shown evidence of retardation by the age of 4 to 6 years. The second group contained 24 patients, of whom 18 had maintained normal or relatively normal intellectual skills throughout childhood with the other six having shown no evidence of delay by the age of 6 years. Of the remaining 12 patients, five were too young for meaningful evaluation, one was case 75 , and the other six came from family $\mathbf{G}$.

Thus, on the basis of intellectual performance alone, the patients could be readily subdivided into two categories corresponding roughly to the 'severe' and 'mild' groups described by Lichtenstein et al. ${ }^{2}$

\section{GENETIC HETEROGENEITY}

The essential question at the heart of this problem concerns whether or not the disorder 'bred true' within families. If so, then it is unlikely that modifying genes or environmental factors or both are responsible for the differences between the severe and mild forms.

Simple clinical assessment of the patients indicates that in 16 of the 17 families there was little, if any, intrafamilial variation in disease severity. The one family in which variation did occur, family $G$, is described in the next section. Clinical impressions may be quantified by comparing variation between and within families for age at death as shown in tables 2 and 3. Comparison of variance between and within these families shows a highly significant difference, an observation consistent with the disorder 'breeding true', but not necessarily implying that this occurred in all of the families studied.

\section{TABLE 2 Age at death of study patients in months.}

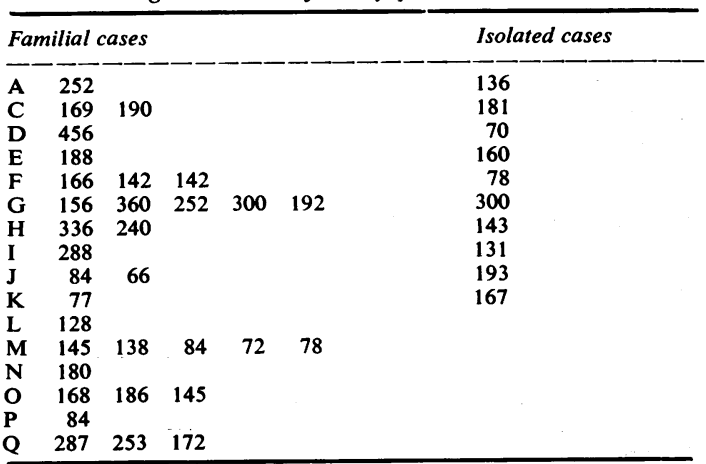

The capital letters refer to individual families. At the time of analysis all affected subjects in family $B$ were alive. 
TABLE 3 One way analysis of variance of age at death, based on a total of 43 patients in 26 kindreds. There are $26-1=25 d f$ representing interfamilial variation and 43-26 = $17 d f$ for intrafamilial variation.

\begin{tabular}{llrrl}
\hline & $d f$ & \multicolumn{1}{l}{$s s$} & \multicolumn{1}{l}{$m s$} & \multicolumn{1}{l}{$F$} \\
\hline Between families & 25 & 276562 & 11062.5 & $4.326 \mathrm{p}<0.01$ \\
Within families & 17 & 43464 & 2556.7 & \\
\hline
\end{tabular}

$\mathrm{df}=$ degrees of freedom

ss $=$ sum of squares

$\mathrm{ms}=$ mean square

$\mathbf{F}=$ variance ratio

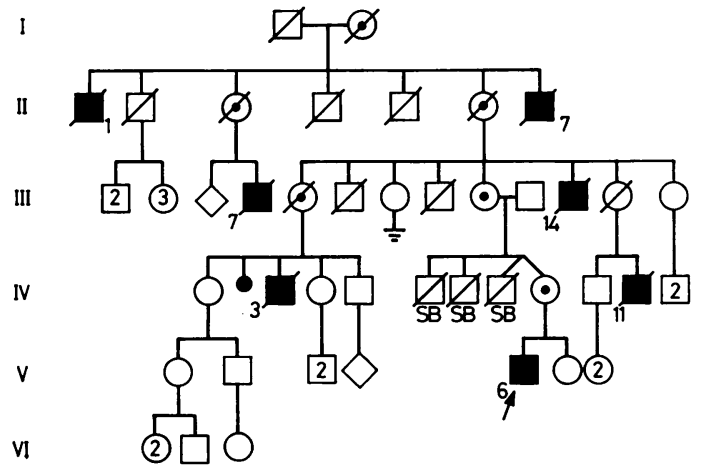

FIG 2 Pedigree of family $G$ based on the original report ${ }^{7}$ and on discussion with living relatives. $S B=$ stillborn.
FAMILY G

The first family to be described showing $\mathrm{X}$ linked mucopolysaccharidosis in the United Kingdom was reported in $1952 .{ }^{7}$ When reviewing published reports, Lichtenstein et $a l^{2}$ concluded that the disease in this family was probably of the severe type, but Spranger ${ }^{3}$ remarked that their disease was 'difficult to assess'.

Review of the affected boys confirms Spranger's impression. During the study one living affected member of this family was encountered (case V.6 in fig 2 and the third patient in fig 3), so that it was possible not only to confirm the diagnosis (serum iduronate sulphatase activity was undetectable) but also to reassess the disease in other affected members, two of whom are also shown in fig 3. The main clinical features in these boys are summarised in table 4.

This family poses two nosological problems. The first is that their disease course, and in particular intellectual performance, appears to lie somewhere near the middle of a hypothetical phenotypic continuum bounded by the extremes of the typical mild and severe cases. Secondly, there appears to be considerable intrafamilial variation in intellectual skills, age at death, and behaviour. For example, case 17 attended normal school at the age of 7 years and showed no behavioural problems, whereas at the same age his first cousin once removed,

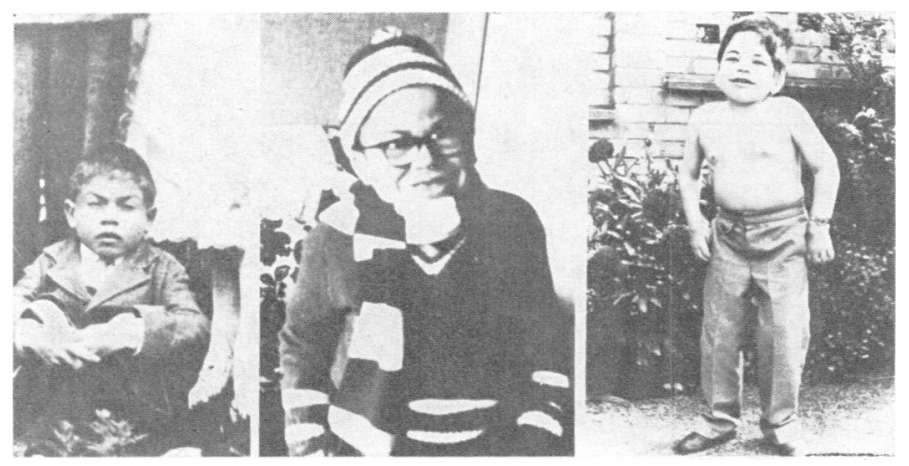

FIG 3 Cases 20,19, and 17 from family $G$ at ages 11,19 , and 17 years respectively.

TABLE 4 Major clinical findings in cases 17 to 22 from family $G$.

\begin{tabular}{|c|c|c|c|c|c|c|}
\hline Case & $\begin{array}{l}\text { Pedigree } \\
\text { No }\end{array}$ & $\begin{array}{l}\text { Age at death } \\
(y r)\end{array}$ & Cause of death & $I Q$ & Behaviour & Other features \\
\hline 17 & $V \cdot 6$ & - & - & $\begin{array}{l}126 \text { at } 4 \mathrm{yr} \\
66 \text { at } 10.8 \mathrm{yr}\end{array}$ & Good & $\begin{array}{l}\text { Pseudopapilloedema } \\
\text { Prepubertal at } 17 \mathrm{yr}\end{array}$ \\
\hline 18 & $\begin{array}{l}\text { IV. } 3 \\
\text { (case } 1 \text { in ref } 7 \text { ) }\end{array}$ & 13 & 'Sudden' & $\begin{array}{l}\text { Mental age }= \\
2 \text { at } 7 \frac{1}{2} \text { yr }\end{array}$ & 'A little terror' & Pronounced hydrocephalus \\
\hline 19 & $\begin{array}{l}\text { IV } \cdot 11 \\
\text { (case } 5 \text { in ref } 7)\end{array}$ & 30 & $\begin{array}{l}\text { Respiratory } \\
\text { obstruction }\end{array}$ & $\begin{array}{l}\text { Mental age }= \\
7 \text { at } 20 \mathrm{yr}\end{array}$ & Good & No puberty by $20 \mathrm{yr}$ \\
\hline 20 & $\begin{array}{l}\text { III } \cdot 14 \\
\text { (case } 2 \text { in ref } 7 \text { ) }\end{array}$ & 21 & 'Heart trouble' & $\begin{array}{l}\text { Could write a little at } \\
11 \mathrm{yr}\end{array}$ & Very overactive & Kept hidden by his family \\
\hline 21 & $\begin{array}{l}\text { II } \cdot 1 \\
(\text { case } 3 \text { in ref } 7)\end{array}$ & 25 & Cardiac failure & $\begin{array}{l}\text { 'Enjoyed looking at } \\
\text { newspapers' }\end{array}$ & Bad tempered & \\
\hline 22 & $\begin{array}{l}\text { II. } 7 \\
\text { (case } 4 \text { in ref } 7)\end{array}$ & 16 & Pneumonia & $\begin{array}{l}\text { Never able to read or } \\
\text { write }\end{array}$ & 'Sweet disposition' & Very small \\
\hline
\end{tabular}


case 18, was in an institution with a mental age of 2 years and was described as 'a little terror' by surviving relatives. While it is possible that parental attitudes may have had a beneficial effect upon initial intellectual assessment in case 17, and conversely a detrimental influence upon behaviour in cases 18, 20 , and 21 , it is unlikely that all of these aforementioned differences were spurious.

\section{LINKAGE}

Little is known concerning the site of the Hunter locus on the $\mathrm{X}$ chromosome. One study has suggested that the Hunter and $\mathrm{Xm}$ loci may be closely linked with a maximum likelihood estimate of $\theta$, the recombination fraction, of $0 \cdot 09 .{ }^{8}$ However, this conclusion was based on the belief that metachromasia in cultured fibroblasts from females at risk indicates definite carrier status, ${ }^{9}$ an assumption which is no longer valid. ${ }^{10}$ There is no other published information concerning the position of the Hunter locus on the $\mathrm{X}$ chromosome, although one large family has been reported in which recombination occurred between the Hunter and $\mathrm{Xg}$ loci. ${ }^{11}$
In the present study none of the families was informative as regards segregation of the Hunter syndrome and defective colour vision. The family pedigrees are shown in full in the appendix. Three families $(C, D$, and $M)$ provided information concerning segregation of the Hunter and $\mathrm{Xg}$ loci, as shown in fig 4 . In family $D$ hair bulb studies performed using the method of Nwokoro and Neufeld ${ }^{12}$ showed no evidence of heterozygosity for Hunter's syndrome in subject IV 3 and so she has been scored as homozygous normal, that is, a recombinant.

The method used in determining possible linkage was the maximum likelihood estimate of the recombination fraction. The lod scores for the three families are shown in table 5 along with the relative probabilities for each value of $\theta$. Clearly these data are not consistent with close linkage between the Hunter and $\mathrm{Xg}$ loci.

\section{Discussion}

The resolution of clinical and genetic heterogeneity within a disease such as Hunter's syndrome is not
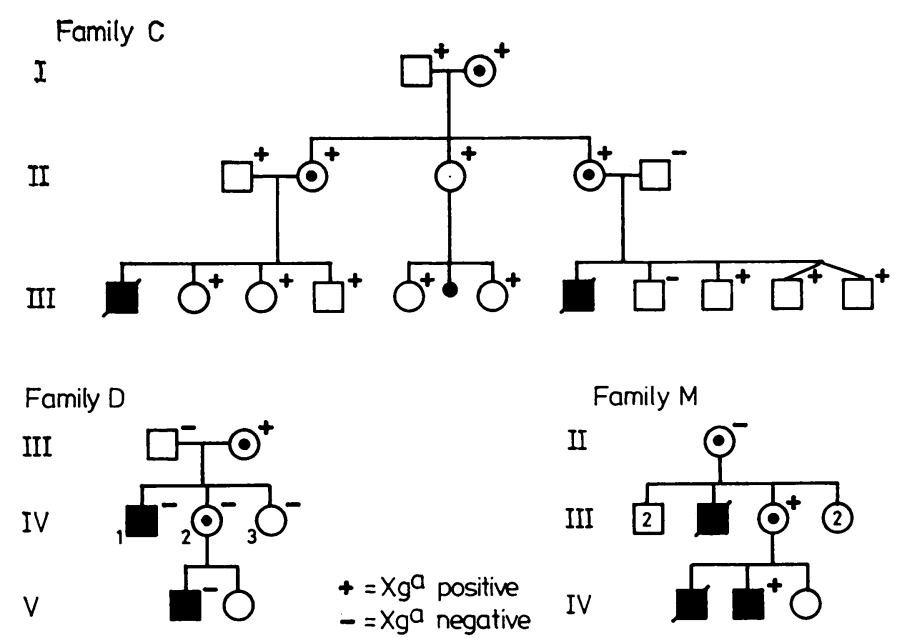

FIG 4 Segregation of the Hunter and $X g$ genes in families $C, D$, and $M$.

TABLF $5 \quad X g$ and Hunter's syndrome. Lod scores and relative probabilities.

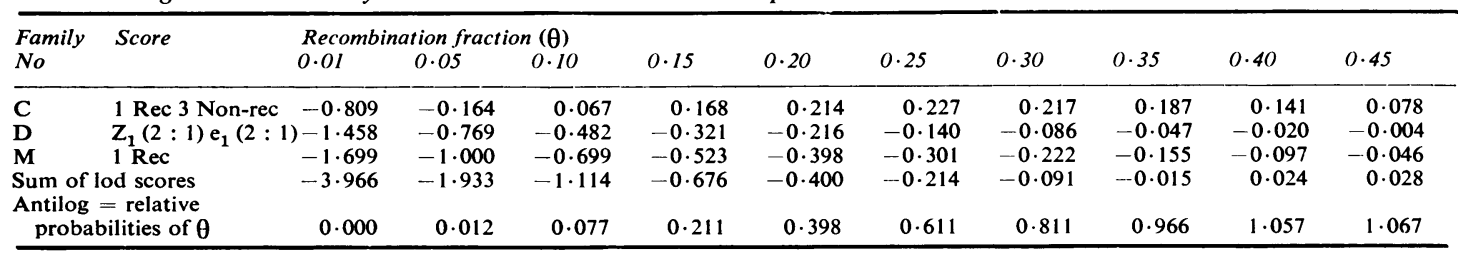

$\mathbf{R e c}=$ Recombinant

Non-rec $=$ Non-recombinant 
simply a subject of esoteric academic interest, since foreknowledge of the probable disease course may influence parents at risk of having an affected child in their decision to embark upon or continue a pregnancy. Thus the papers of Thurmon $e^{2} a l^{4}$ and Yatziv et $a l^{5}$ created serious difficulty for those involved in counselling parents at risk.

In the first of these papers ${ }^{4}$ it was stated that cases within each sibship were more similar to one another than to other affected family members. The authors suggested that this might be attributed to the epistatic effects of other genes, possibly those situated on the $Y$ chromosome. In the present study no such effect was noted in any of the families.

Yatziv et $a l^{5}$ described two families each purported to show mild and severe cases within a sibship. In one of these sibships the severely affected child had IQ assessments of 60 and 58 at ages $2 \frac{1}{2}$ and 10 years respectively. In the other sibship the severely affected child showed very slow psychomotor development, not gaining head control until 5 years or sitting up until 7 years.

The present study suggests that neither of these boys had the typical severe form of Hunter's syndrome as delineated in the accompanying paper. We wonder if the first boy's non-progressive mental retardation might be more reasonably attributed to his perinatal asphyxia or alternatively serve as an example of the slight impairment of intellectual skills apparent in some mild cases of the disease. The profound psychomotor developmental delay in the second child was much more severe than that encountered in any of the severely affected boys in the present study, all of whom showed reasonably normal early motor milestones.

Our results indicate that patients with Hunter's syndrome can be subdivided into two main types, the severe showing longitudinal intellectual decline and the mild maintaining normal or relatively normal intellectual performance. The essential difference between these two forms is the progressive nature of the neurological damage in the former, consistent with the pathological neuronal storage seen at necropsy. ${ }^{13}$ In addition, our study suggests that in most families little intrafamilial variation occurs, an observation in keeping with true genetic heterogeneity.

The pattern of disease in family $G$ defies easy classification. Although the proband, case 17, showed a 60 point drop in IQ between the ages of 4 and 11 years, his subsequent progress at special school indicated no further loss in intellectual skills, and clinical examination at 17 years revealed no evidence of the neurodegeneration so characteristic in the severely affected boys. However, the natural history in case 18 is certainly consistent with severe disease. Possibly some of the nosological confusion in this family has arisen because of the superimposed effects of a secondary complication such as hydrocephalus. Alternatively this family may be the repository of a unique mutation, the effects of which can be modified by other unknown factors.

At the outset of the study it was hoped that linkage analysis might indicate whether the mild and severe forms are allelic. Unfortunately insufficient informative families could be found. The linkage data are included here so that they may be combined with information forthcoming from other centres. The disease in families $C$ and $M$ was of the severe type: affected members in family $\mathrm{D}$ had mild disease. If it is assumed that the mild and severe forms are allelic, as seems probable since they appear to share the same basic defect, then this study suggests that the Hunter and $\mathrm{Xg}$ loci are unlikely to be closely linked.

\section{References}

1 McKusick VA, Pyeritz RE. Genetic heterogeneity and allelic variation in the mucopolysaccharidoses. Johns Hopkins Med J 1980;146:71-2.

2 Lichtenstein JR, Bilbrey GL, McKusick VA. Clinical and probable genetic heterogeneity within mucopolysaccharidosis II. Report of a family with a mild form. Johns Hopkins Med J 1972;131 :425-35.

3 Spranger J. The systemic mucopolysaccharidoses. Ergeb Inn Med Kinderheilkd 1972;32:165-265.

4 Thurmon TF, DeFraites EB, Anderson EE. Clinical heterogeneity in mucopolysaccharidosis II: evidence for epistasis. Birth Defects 1974;10:125-7.

5 Yatziv S, Erickson RP, Epstein CJ. Mild and severe Hunter syndrome (MPS II) within the same sibships. Clin Genet 1977;11:319-26.

- Archer IM, Harper PS, Wusteman FS. An improved assay for iduronate 2-sulphate sulphatase in serum and its use in the detection of carriers of the Hunter syndrome. Clin Chim Acta 1981 ;112:107-12.

7 Millman CG, Whittick JW. A sex-linked variant of gargoylism.J Neurol Neurosurg Psychiatry 1952;15:253-9.

8 Berg K, Danes BS, Bearn AG. The linkage relation of the loci for the Xm serum system and the X-linked form of Hurler's syndrome (Hunter's syndrome). Am J Hum Genet 1968;20:398-401.

- Danes BS, Bearn AG. Hurler's syndrome. A genetic study in cell cultures. J Exp Med 1966;123:1-16.

10 Taysi K, Kistenmacher ML, Punnett HH, Mellman WJ. Limitations of metachromasia as a diagnostic aid in pediatrics. N Engl J Med 1969;281:1108-11.

11 Passarge E, Wendel U, Wöhler W, Rüdiger HW. Krankheiten infolge genetischer defekte im lysosomalen mucopolysaccharid-abbau. Dtsch Med Wochenschr $1974 ; 99: 144-58$.

12 Nwokoro N, Neufeld EF. Detection of Hunter heterozygotes by enzymatic analysis of hair roots. Am J Hum Genet $1979 ; 31: 42-9$.

13 Njà A. A sex-linked type of gargoylism. Acta Paediatr Scand 1946;33:267-86.

Requests for reprints to Dr I D Young, Department of Child Health, Leicester Royal Infirmary, PO Box 65, Leicester LE2 7LX. 
406

I D Young, PS Harper, I M Archer, and R G Newcombe

APPENDIX Full pedigrees of 14 of the 17 study families. No pedigree could be obtained for family E, in whom the affected members consisted of an uncle and nephew. The pedigree of family $G$ is shown in fig 2 and the full pedigree of family $C$ appears in fig 4.

Family $\dot{A}$

I

II

III

IV

$\square \infty$

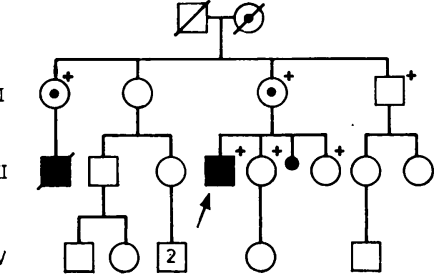

Family $\mathrm{H}$

I

II

III

IV
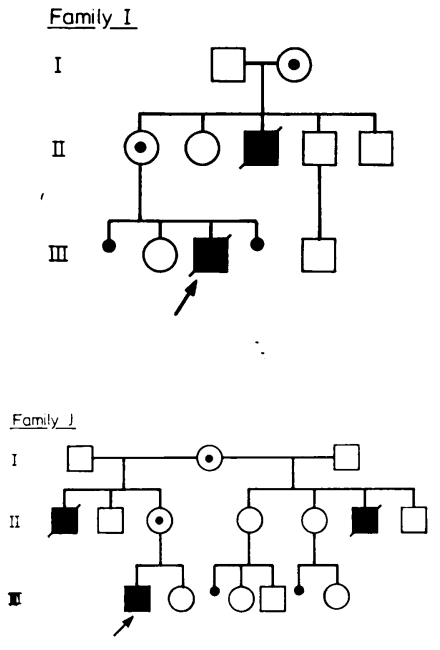

Family $K$

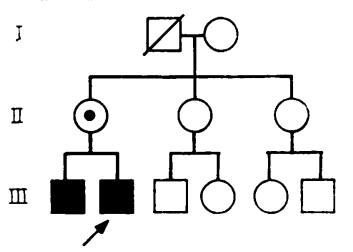

Family $L$

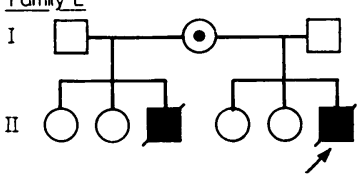

$\mathrm{SB}=$ stillborn

Family I
Family $F$

I

II

III

IV
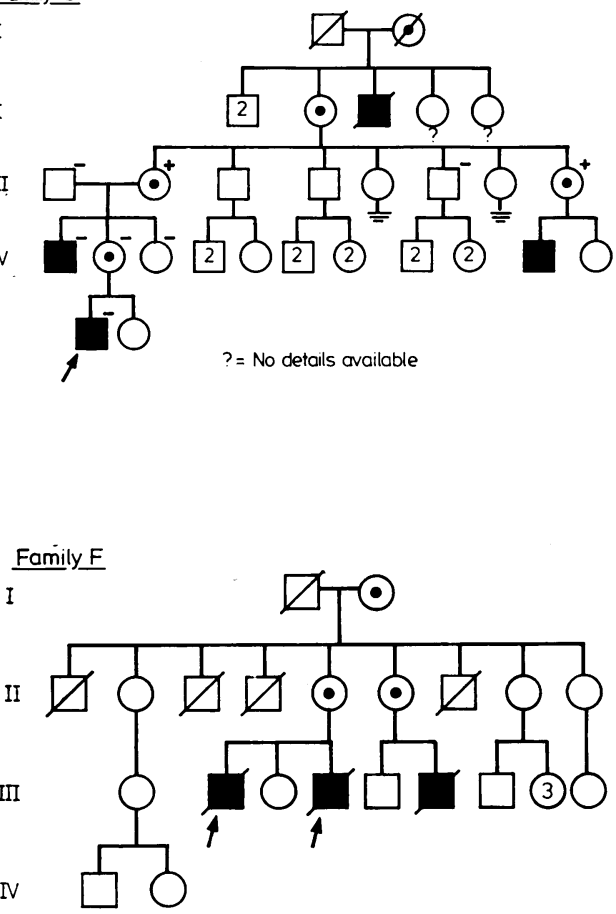

$\frac{c}{3}$

Family B

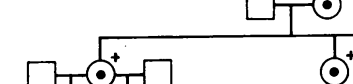

$+\square$

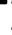

A

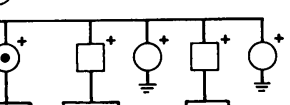

自定自己

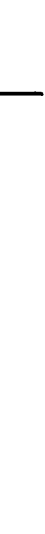

.

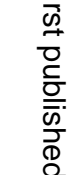

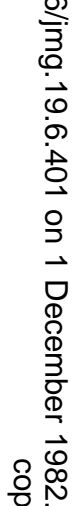

할

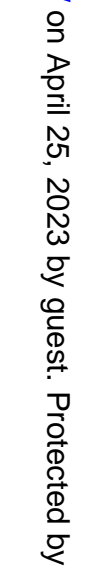


Appendix-cont.
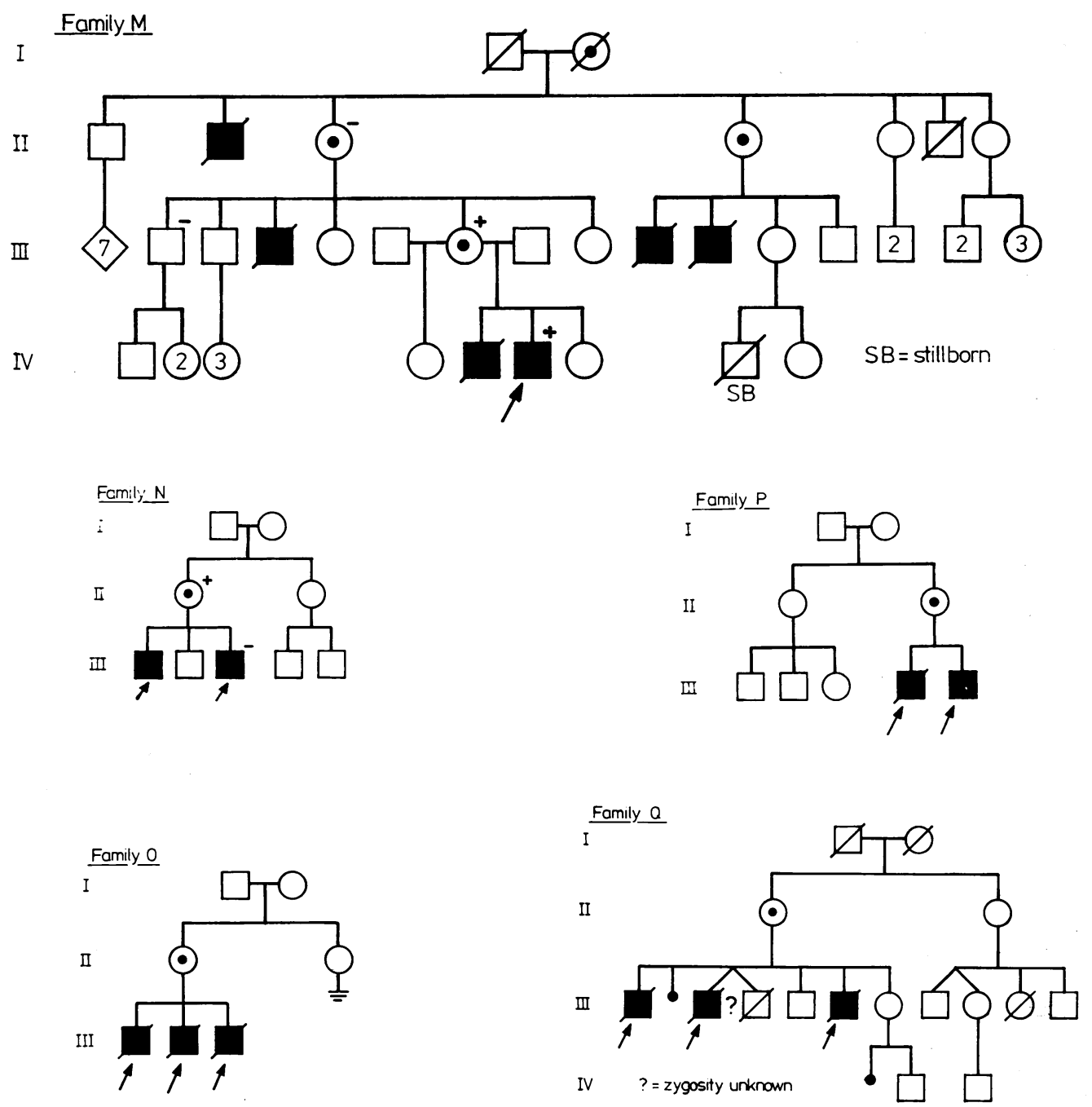